\title{
TRENDS IN PAYMENT CARD ACCEPTANCE ON THE INTERNET
}

\section{Zoran Jović Goran Ćorić}

\author{
${ }^{1}$ Singidunum University, \\ Belgrade, Serbia \\ ${ }^{2}$ Raiffeisen Bank Serbia \\ Belgrade, Serbia
}

\begin{abstract}
:
The development of information and telecommunication technologies corresponds directly to an increase in the Internet application in modern banking and commerce. Acceptance of payment cards on the Internet is increasing, the aim being to enable safe and secure way of non-cash payment for goods and services purchased by means of payment cards. Banks and commercial companies have a shared interest in increasing their volume of business by developing a variety of options for payment card acceptance on the Internet, enhancing their clients'/buyers' satisfaction, increasing speed and security of transactions, lowering their operational costs and increasing profit margins. In order to follow trends in payment card acceptance on the Internet in the world, and in Serbia, as well, it is necessary to analyse consumer trends in that particular market, potential and capacity of the market, as well as the Internet infrastructure of the same market. For this purpose, segmentation of a potential market for payment card acceptance on the Internet is analysed, market conquering strategies are studied and ways for overcoming barriers hampering the growth of this method of payment are devised.
\end{abstract}

\section{Keywords:}

e-Commerce, webshop, payment cards, Internet.

\section{INTRODUCTION}

Payment card acceptance on the Internet or e-commerce has been developed with the aim of enabling safe and secure way of non-cash payment by means of payment cards at a point of sale - webshop. An Internet point of sale, also known as Web-shop, represents a virtual point of sale where payment cards are accepted as a non-cash method of payment for goods and services via the Internet exclusively. Payment card transactions on the Internet involve using information and telecommunication technologies that offer advantages of time and space limitlessness, high speed of transaction and low prices. On the other hand, apart from the obvious benefits, these transactions also pose certain risks that need to be accurately identified and managed.

Payment cards are one of the most massively used means of electronic banking. In addition to being used as a means of payment for goods and services, cash withdrawals and electronic payments, they offer the convenience of currency conversion. In this way a client can make a payment in any country regardless of the currency of payment, and their account is debited from in domestic currency. Rapid development of payment cards and the ensuing substantial financial potential led to the creation of large international credit card franchise chains such as Visa, MasterCard, Diners Card, American Express. ${ }^{1}$

The Internet is ubiquitous and global by nature. It is an open, highly accessible network used by unknown parties routing messages by means of unknown locations and via fast evolving wireless devices. This considerably enhances the importance of

1 Jović Z., Ćorić, G., Pejović, I. (2016). Challenges of Modern Electronic Banking. Paper presented at Sinteza 2016 - International Scientific Conference on ICT and E-Business Related Research. doi:10.15308/Sinteza-2016-442-447 
security controls, customer authentication techniques, data protection, audit trail procedures, and customer privacy standards. ${ }^{2}$

\section{ADVANTAGES OF E-COMMERCE}

There are numerous advantages of this method of sale for both merchants and buyers. Advantages for the merchant reflect in the low cost of setting up an Internet point of sale compared to a standard point of sale, availability of goods and services to buyers across the world and convenience of 24/7 service. Benefits of e-commerce for buyers result from availability of all products 24 hours a day, the option of the so-called buying while seated in an armchair, lower prices of goods, easier comparison of prices of goods and services on the market, a greater choice of products, better information about product characteristics and consumer impressions, avoidance of pressure by salespersons and reduced cost of purchase of products.

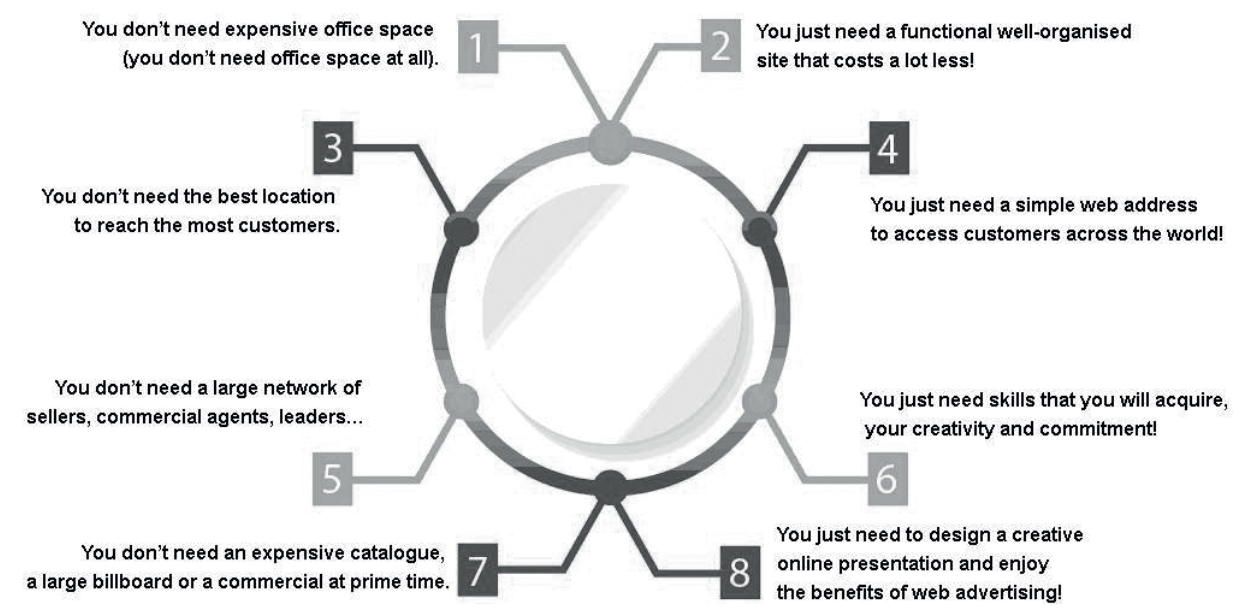

Source: www.e-commerce service

\section{PAYMENT SECURITY ON THE INTERNET}

Security of electronic commerce, that is, payment on the Internet has particular importance.

Smart or payment cards have an integrated circuit or chip containing a processor and memory. This chip can store certain data in a secure way. The beauty of the technology of smart cards is the variety of potential uses. A smart card offers an assortment of applications relating to digital signature, purchase, copyright protection, electronic purchase, and the like. Depending on the type of the chip embedded, smart cards can be memory, microprocessor or combined cards, as well as contactless smart cards which contain a miniature antenna that allows wireless sending and receiving of information in the wireless communication network. In comparison with conventional payment cards, smart cards have significant benefits relating to security, convenience of use, economic benefits, adaptability to specific needs and multifunctionality. ${ }^{3}$
2 Risk Management Principles for Electronic Banking, Basel Committee on Banking Supervision, July 2003, pp.5-6.
Major payment card associations such as MasterCard and Visa have devised their own security programmes for purchase on the Internet. These programmes are based on the 3-D Secure model and are called MasterCard Secure Code and Verified by Visa. These names denote points of sale on the Internet that provide security standards on their Web pages. The 3-D Secure programme allows users to verify their authenticity to the issuing bank while using the payment card on the Internet and performing a transaction. This contributes to risk protection and protection against fraud when an unauthorised use of a payment card is made on the Internet by a third party that is not an authentic cardholder.

3 Jović Z., (2014). Primena interneta u savremenom bankarskom i berzanskom poslovanju, Međunarodna naučna konferencija Sinteza 2014: Uticaj Interneta na poslovanje u Srbiji i svetu, Zbornik radova, Beograd, 25.-26.04.2014-180-185 


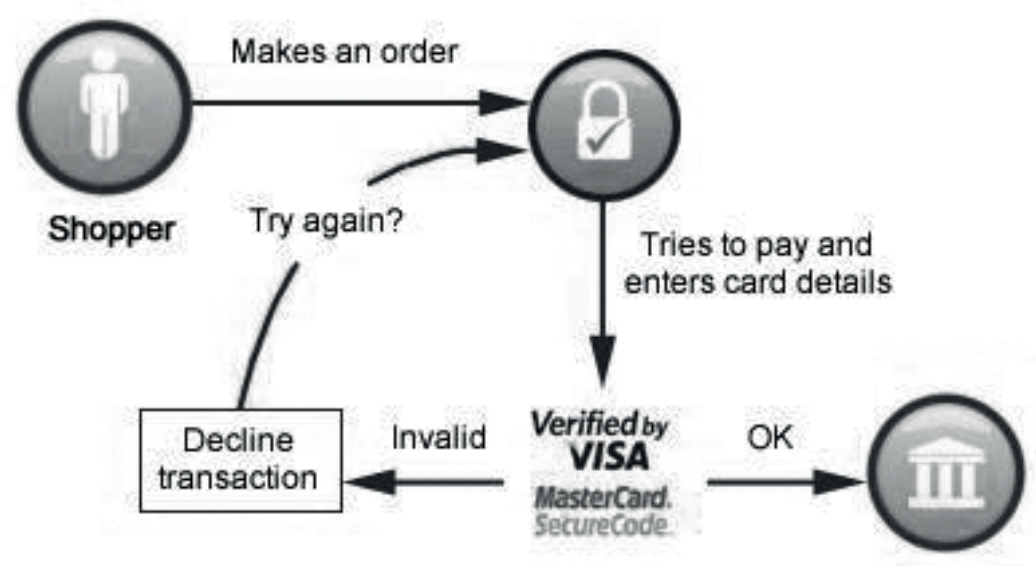

Source: Raiffeisen Bank: 3D Secure Service

The National Bank of Serbia has issued a recommendation for safe use of payment cards at an Internet point of sale: ${ }^{4}$

- When making a payment on the Internet, use verified and well-known sites that provide security standards of MasterCard SecureCode and Verified by Visa

- Due to an increase in the number of fake sites that look just like the original ones, never enter your PIN number on any site

- Before entering your card number, make sure that there is a lock or a key at the bottom the Web browser as these are the signs of a protected Internet connection. The beginning of the Merchant's Internet address should read 'https' instead of 'http' as this denotes a secure connection.

Security Control should be given special attention because of security challenges posed by e-banking. In this category, the following principles are of particular importance:

- Authentication of e-banking customers,

- Non-repudiation and accountability for e-banking transactions,

- Data integrity of e-banking transactions, records and information,

- Appropriate measures to ensure segregation of duties,

- Proper authorisation controls within e-banking systems, databases and applications,

- Establishment of clear audit trails for e-banking transactions,

- Confidentiality of key bank information.

4 www,nbs.rs

5 Jović Z., Ćorić, G., Pejović, I. (2016). Challenges of Modern Electronic Banking. Paper presented at Sinteza 2016 - International Scientific Conference on ICT and E-Business Related Research. doi:10.15308/Sinteza-2016-442-447

\section{PAYMENT CARD FRAUD}

Payment card fraud that occurs while purchasing goods and services on the Internet is becoming an increasingly common type of crime in the world. The fraudulent action itself can be performed without the actual card because this type of fraud is carried out by using the card number and the CVV2 number which stands for Card Verification Value 2 a three-digit number on the back of the card. In order to carry out a fraudulent action on the Internet it is enough to have the card number, its expiration date and the CVV2 number. These data enable purchase on the Internet without actually having a physical card in possession. Such unauthorised obtaining of data can be carried out in a number of ways: by copying data from the card, photocopying the front and back sides of the card or applying phishing and pharming.

One of the most commonly applied fraudulent techniques when targeting participants in electronic commerce is identity theft. This theft can be performed in different ways, the most common and most sophisticated ones being phishing (one user is targeted), pharming (a group of users is targeted), and taking advantage of insufficiently informed users. $^{6}$

The most common type of fraud that involves obtaining confidential cardholder data is phishing. This method induces cardholders to disclose their confidential personal data such as Unique Master Citizen Number, card number, PIN, user name and password, etc. This inducement is carried out by sending fake messages by electronic mail and using fake web pages, most often pages of banks and other financial institutions. Phishing attacks are performed using e-mail messages containing fake warnings, messages and

6 Jović Z., Ćorić G., (2014). Bezbednost elektronskog poslovanja u bankarstvu, XV Međunarodni naučni skup Sinergija 2014, Zbornik radova, $\mathrm{BiH}$, Bijeljina, decembar, 2014-143-146 
information. These are very often found in the form of fake warnings by banks that the client's account was to be closed unless the client supplied updated data, when in fact they were being stolen by unauthorised persons. Then there are messages warning of security risks and urging clients to disclose personal information pertaining to user account, password and the like. There are also those messages that call for the installation of a particular programme for the purposes of eliminating an allegedly detected security risk. There are also fake messages by administrators asking for cardholder data such as password. These include messages that inform users of winning the lottery where it is necessary to supply certain information in order for the transfer to be effected, when in fact these data are the sole purpose of the fraudulent action.

Pharming is a type of fraud that involves re-directing Internet traffic from the original website to a fake one. A payment cardholder, while connecting to a bank's website or another financial institution's website and entering the website address, is re-directed to another site, a fictional, cloned site whose appearance is almost identical to the original site. The subsequent steps in further feeding of data and their theft are similar to those in phishing. The difference between phishing and pharming lies in who is targeted. The target in phishing is a large number of individuals that are targeted one at a time, while with pharming the whole process is completed in a short period of time when a large number of Internet users is re-directed from original to fake commercial sites.

There are also other types of credit card fraud. Card number may be fraudulently used to order goods and services by phone or mail, and then such goods and services are sold at half price. This practice is known as MOTO - Mail Or Telephone Order. Payment card fraud can take place using computers to transfer data from the skimmer to the printer, or to hack a merchant's data base holding confidential client data such as card numbers, credit card magnetic stripe information, etc., or they can be used to apply software to generate the card number, etc.

Although considerable measures are being taken to fight cyber-crime, an increase in the number of services provided by banks and other financial institutions causes a considerable rise in the number of users of electronic services who, owing to insufficient information they receive, are an easy prey for much better organised cyber criminals. At present, the existing systems and mechanisms provide a high level of protection against online banking fraud and robbery, but none of them can fully protect the bank and its clients. However, the security of transactions via the network must be the key principle every bank shall abide by and define their service scope accordingly.

7 Jović Z., Ćorić, G., Pejović, I. (2016). Challenges of Modern Electronic Banking. Paper presented at Sinteza 2016 - International Scientific Conference on ICT and E-Business Related Research. doi:10.15308/Sinteza-2016-442-447

\section{GLOBAL AND LOCAL STRATEGIES OF PAYMENT} CARD ACCEPTANCE ON THE INTERNET

In defining strategies of payment card acceptance on the Internet one should start from the real situation in e-commerce market. It is characterised by three main facts:

- transaction security is one of the main barriers to clients completely embracing e-commerce. Furthermore, clients deem that there is a high risk of delivery of poor quality or damaged goods when the payment is made in advance

- cardholders are aware of the most important benefits of this method of payment, and they are: simplicity of use, payment process speed and wide acceptance of this method of payment

- the cash on delivery payment method remains the most common method of payment in retail, even in big e-commerce trade chains

The whole e-commerce market can be divided into four segments:

- non-user segment

- emerging segment

- evolving segment

- mature segment.

The non-user segment refers to clients who do not make any purchases on the Internet but they are active Internet users who browse for products and services. The emerging segment refers to clients who have already established themselves as Internet payment users but belong to one of the beginner categories who use this method of payment to pay bills, for travel and fashion. The evolving segment refers to users who have already taken advantage of making payment on the Internet in the previously mentioned three categories, and are now establishing themselves in another three categories: fashion\&beauty, electronics and entertainment. The mature segment refers to clients who make payment on the Internet in all of the above six categories, as well as in the following categories: cosmetics, food delivery, groceries, digital content, digital books, CDs and DVDs. The target group for payment card acceptance on the Internet should be the persons in the non-user segment and the emerging segment. The strategy should be focused on applying global principles and devise means to fortify security characteristics of the process and emphasise benefits of online purchasing, so as to induce clients to make payment on the Internet. With this goal in mind, the strategy devised should be efficient and focused on market communication that enhances the use of e-commerce.

In creating a successful strategy of payment card acceptance on the Internet, the existing barriers hampering acceptance and growth of e-commerce should be identified and their elimination worked on. The most important consideration should be given to the fact that cardholders value the 
security of online transactions most and that the possibility of fraud is their main concern. According to some surveys, online security concern is predominant in $58 \%$ percent of the respondents on the global level, and a similar percentage of $60 \%$ in Serbia. Unwillingness to reveal personal information and credit card information is recorded in $42 \%$ of respondents worldwide. In the world, the habit of paying cash or using other methods of payment is characteristic of $23 \%$ of the survey participants, while in Serbia that figure is higher and it is $47 \% .19 \%$ of respondents reported having experienced failures in online transactions when using payment cards. Overcoming these barriers is the key to greater acceptance of payment cards on the Internet.

\section{Trends in online payment}

The reason why online payment volume is growing worldwide is obvious. This growing trend stems from the very nature of Internet payment that offers benefits such as time-saving, a wide variety of goods and services, easy comparison of prices and quality of goods on offer, not having to wait in long queues and lower prices of goods on offer in comparison with other methods of purchase. That is why $87 \%$ of all Internet users across the world have performed at least one payment transaction online, while $60 \%$ completed more than one payment transaction online. It is estimated that in the near future almost $10 \%$ of the entirety of retail transactions shall be carried out online. According to the data by Euromonitor International sale value of Internet retail, excluding taxes, is on the rise in all parts of the world. Viewed globally, in 2009 this method of sale participated with the share of $2.7 \%$, in 2014 with $5.8 \%$, and it is estimated that in 2019 it will reach $8.9 \%$. The most rapid expansion is recorded in China with $0.3 \%, 8.5 \%$ in 2009 and 2014 respectively and estimated $13.9 \%$ in 2019 , followed by South Korea with $9.9 \%, 13.7 \%$ and $17.4 \%$, USA with $4.6 \%, 8.4 \%$ and $12.1 \%$, Taiwan with $4.3 \%, 8.2 \%$ and $11.4 \%$ in the same years respectively. Western Europe countries record a share of $3.1 \%, 6.6 \%$ and $10.1 \%$, while Eastern Europe countries record a share of $1.7 \%, 3.5 \%$ and $5,6 \%$ in the same years respectively.

The best-selling categories of goods and services on the Internet are: plane tickets and reservations; clothes, accessories and shoes; tourist and hotel reservations; tickets for events; books; electronic equipment; e-books; mobile phones; sports equipment; cosmetics; computer hardware; personal care products; toys and dolls; videos, DVDs and games; computer software; music; groceries; pet products; baby gear; flowers; cars, motorcycles and gear and accessories; alcoholic beverages.

Online shopping is no longer done by means of computers only as more and more people do it over the mobile phone. This trend is developing owing to an increase in the use of smartphone technology in mobile telephony. According to the data by Statistics portal, in the five-year period 2014-2018 the penetration of smartphone users in the total world population was $24.5 \%, 28.2 \%, 31.3 \%, 34.2 \%, 36.5 \%$ by year respectively, including the estimates for 2017 and 2018. When these percentages are interpreted in numbers of smartphone users, they amount to 1.57 billion; 1.86 billion; 2.1 billion; 2.32 billion and 2.53 billion users respectively in the same years.

Internet infrastructure in Serbia has enough capacity for growth of payment via the Internet. In 2016 over 60\% of households owned computers that allowed broadband Internet connection and $63 \%$ of households had cable TV. Estimates indicate that in 2030 the percentage of households owning computers that allow broadband Internet connection will reach upwards of $80 \%$, while the percentage of households owning cable TV will rise to around $70 \%$.

Currently there are 250 online traders in Serbia. The overall volume of payment in Serbia can be divided into faceto-face payment and e-commerce, where face-to-face payment accounts for $93 \%$ of the total volume and e-commerce for $7 \%$.

Consumer habits in Serbia differ based on the manner of purchase and method of payment. The classical face-to-face method of payment is most commonly applied at discount stores, mechanic's, convenience food stores, restaurants, cosmetics stores and pharmacies, clothes stores and supermarkets, furniture stores.

The e-commerce method of payment i.e. using payment cards on the Internet is most commonly used in Serbia to purchase plane tickets, pay at bookmakers, casinos and lottery, pay for telecommunication services, at a variety of stores, theatres, restaurants, insurance, computers, electrical parts and equipment, telecommunication equipment.

According to a research carried out in Serbia, better prices and a wider choice are the main e-commerce incentives.

The research has shown that local web shops are more popular than international ones. Active payment cardholders in Serbia perform 13 transactions on the Internet on an average annually. As far as the method of payment is concerned, cash is most commonly used to pay for delivery in $47 \%$ of cases, whereas when it comes to payment cards the most commonly used ones are debit cards at $28 \%$, Internet cards at $13 \%$ and credit cards at $7 \%$. Payment slip is used by only $4 \%$ of online shoppers in Serbia. The most common products bought on the Internet are clothes and shoes $44 \%$; electronic equipment $33 \%$; or paying household bills in $18 \%$ of cases.

\section{CONCLUSION}

The strategy that should be employed to increase the acceptance of payment cards on the Internet should be focused on the target group incorporating the non-user segment and the emerging segment, keeping in mind the barriers hampering the acceptance and growth of e-commence and what needs to be done to overcome them. The sale value 
of Internet retail is on the rise in all parts of the world, and online shopping is more and more done using mobile telephony. Electronic payment volume is increasing in Serbia and according to reports by the National Bank of Serbia, in 2015 online bank transactions were more numerous than traditional transactions, the trend being in favour of electronic transactions. However, e-commerce has not expanded sufficiently yet. According to the data by the Bureau of Statistics of the Republic of Serbia, over 54\% of Internet users have never shopped or ordered goods online but the number of users performing such transactions is on the rise. This rise in the number of Internet users in Serbia is also the result of the global trend which reflects that the Internet is now readily accessed on mobile phones, rather than on computers, and the penetration of mobile phones in Serbia in relation to the number of inhabitants is $129 \%$, especially the penetration of smartphones that is rapidly increasing.

\section{LITERATURE}

Jović Z., Ćorić G., Pejović I., (2016). The challenges of modern electronic banking, Međunarodna naučna konferencija Univerziteta Singidunum Sinteza 2016 (Sinteza 2016, International Scientific Conference on ICT and E-Business Related Research) Zbornik radova, Beograd, 22-23.04.2016442-447

Jović Z., Ćorić G., (2014). Bezbednost elektronskog poslovanja u bankarstvu, (2014). XV Međunarodni naučni skup Sinergija 2014, Zbornik radova, BiH, Bijeljina, decembar, 2014143-146

Jović Z., (2014). Primena Interneta u savremenom bankarskom i berzanskom poslovanju, Međunarodna naučna konferencija Sinteza 2014: Uticaj Interneta na poslovanje u Srbiji i svetu, Zbornik radova, Beograd, 25.-26.04.2014-180-185

Risk Management Principles for Electronic Banking, Basel Committee on Banking Supervision, July 2003, pp.5-6.

Euromonitor International

GM Business\&Lifestyle 16.12.2016.

www.e-commerce service

www.nbs.rs

www.raiffeisenbank.rs 